\title{
Signaling by exosomal microRNAs in cancer
}

\author{
Germana Falcone ${ }^{1 *}$, Armando Felsani $i^{1,2}$ and Igea D'Agnano ${ }^{1 *}$
}

\begin{abstract}
A class of small non-coding RNAs, the microRNAs (miRNAs), have recently attracted great attention in cancer research since they play a central role in regulation of gene-expression and miRNA aberrant expression is found in almost all types of human cancer. The discovery of circulating miRNAs in body fluids and the finding that they are often tumor specific and can be detected early in tumorigenesis has soon led to the evaluation of their possible use as cancer biomarkers and treatment-response predictors. The evidence that tumor cells communicate via the secretion and delivery of miRNAs packed into tumor-released microvesicles has prompted to investigate miRNA contribution as signaling molecules to the establishment and maintenance of the tumor microenvironment and the metastatic niche in cancer. In this review we highlight the recent advances on the role of exosomal miRNAs as mediators of cancer cell-to-cell communication.
\end{abstract}

Keywords: Small non-coding RNAs, Tumor, Exosomes, Cell-to-cell communication

\section{Introduction}

microRNAs (miRNAs) are a family of endogenous, noncoding, tiny RNA molecules which modulate gene expression functioning both by targeting messenger RNA degradation and suppressing protein translation. Thousands of human protein-coding genes are regulated by miRNAs, indicating that miRNAs are master regulators of diverse biological systems, facilitating a rapid response of body physiology. miRNAs have been shown to regulate every aspect of cellular activity, including differentiation and development, metabolism, proliferation and apoptosis. In addition, the biogenesis and function of miRNAs are related to the molecular mechanisms of various diseases including cancer. The intensive research of the past years have demonstrated that miRNAs are not only contained into cells, but are also detectable outside them, secreted in various body fluids (e.g. serum, plasma, saliva, urine) routinely examined in patients $[1,2]$. It is known that extracellular miRNAs are included in small membranous vesicles or packaged with RNAbinding proteins [3]. miRNAs contained into microvesicles, and in particular into exosomes, have been shown to function as secreted signaling molecules that influence the recipient cell phenotypes. Furthermore,

\footnotetext{
*Correspondence: germana.falcone@cnr.it; igea.dagnano@cnr.it ${ }^{1}$ Institute of Cell Biology and Neurobiology, CNR, Via Ramarini 32-00015, Monterotondo, RM, Italy

Full list of author information is available at the end of the article
}

secreted exosomal miRNAs may reflect the molecular changes of the cells from which they originate and can therefore be seen as potential indicators for early recognition of the onset of disease. In addition, since they are relatively stable, disease-specific and can be efficiently detected in body fluids and amplified by means of molecular biology tools such as real-time PCR, they can be seen as ideal biomarkers in many pathological states including cancer.

Thanks to their unique properties and functions, miRNAs play a crucial role in human cancer development and tumorigenesis as their expression is frequently deregulated in many types of tumors, functioning either as tumor suppressors or as oncogenes (oncomiRs). Furthermore, miRNAs were shown to be responsible for cancer-related inflammation, cancer drug resistance, and regulation of cancer stem cells. Therefore, miRNAs have generated great interest as a novel strategy in cancer diagnosis and therapy [4].

\section{Exosomal miRNAs}

The first observations that mature miRNAs are present in cell-free blood plasma and serum was made in 2008 by several independent research groups [5-8]. Later, nuclease resistant extracellular miRNAs have been found in all known biological fluids [9-12]. Since then, accumulated reports have consistently shown that extracellular miRNAs can be shielded from RNAse degradation 
by: (1) packaging in microvesicles (MVs) such as apoptotic bodies, shedding vesicles and exosomes; or (2) solely by complexing with AGO proteins [13-15]. Most miRNAs present in biological fluid have been found MVs-free and associated with proteins of the Ago family, which appear remarkably stable even in protease rich environment $[16,17]$. Some miRNA species were also found in purified fractions of high-density lipoprotein (HDL) from human plasma [18,19], although the analyzed HDL-miRNAs constituted only a minor proportion of the total circulating miRNAs. Circulating miRNAs bound by Ago proteins are apparently non-specific remnants resulting from physiological activity of the cells and cell death [15,17]. On the contrary, extracellular miRNAs included within MVs can be transferred to recipient cells, alter gene expression and mediate functional effects [20-25].

\section{Exosomes}

Exosomes are membrane vesicles of an average 30$100 \mathrm{~nm}$ diameter, are formed within the multivesicular bodies (MVBs), also known as late endosomes, and released upon fusion of MVBs with the plasma membrane [26] from many different cell types in the body, such as red blood cells, platelets, lymphocytes, dendritric cells, and tumor cells. Exosome composition does not merely reflect the cells of origin, but is enriched in specific proteins, lipids and RNAs, indicating the existence of specialized sorting mechanisms, most of which are not fully understood [27]. Exosome membranes are enriched in cholesterol, sphingolipids, glycerophospholipids and ceramide [28], and bear both intraluminal and transmembrane proteins, with the same polarity as the plasma membrane. Proteins enriched in exosomes include tetraspanins (CD63, CD81) and associated proteins such as integrins, immunoglobulins and growth factor receptors; cytoskeletal proteins (tubulin, actin); ESCRT-related proteins (Alix, Tsg101); heat-shock proteins (hsp70, hsp90), and proteins involved in vesicle trafficking such as Rab GTPases, annexins and flotillin [29,30]. Exosomes are also enriched in mRNAs and small RNA species, including vaultRNA, tRNAs and miRNAs [31]. Recently, tumor-derived exosomes have been shown to carry single and double stranded DNA $[32,33]$.

The profile of miRNAs in exosomes is specific, since particular repertoires of miRNAs are selectively sorted, while others are usually excluded. Moreover, profiling studies have revealed that exosomes of different cellular origin contain a unique expression profile of mRNAs and miRNAs, which may also differ from the signatures of their parent cells [24,34,35]. Hence, exosome content reflects the nature and even the state of the producer cell. A searchable compendium of exosomal proteins and RNA is now accessible at ExoCarta (http://www.exocarta.org/). A recent study on exosomes released from human colon carcinoma cells and purified by immunocapture with different antibodies revealed two different exosome populations distinct for both protein and miRNA composition [36]. Interestingly, miRNA passenger strands were particularly enriched in one exosomal population, suggesting that miRNA biogenesis may be interlinked with endosomal/exosomal processing [36].

The exosome composition is crucial in determining the outcome of the communication between donor and recipient cells. The mechanism of exosome-mediated cell-to-cell communication is particularly important in cancer, since tumor cells constitutively secrete exosome, which can target locally adjacent cells of the same type (autocrine effect), neighboring cells of different types (paracrine effect), or reach cells located at distant organs after entering the blood stream (endocrine effect). These exosomes play a key role in the modulation of the immune response against the tumor [37-41], the induction of angiogenesis [24,42], cell invasion and metastasis $[43,44]$. Tumor cells are continuously subjected to a range of stressors such as hypoxia, starvation or chemotherapeutic agents, and cancer progression depends on the ability of cells to sense and adapt to these situations. miRNA-based intercellular communication relies on critical processes. First, miRNAs must be selectively and actively secreted from cells and packaged into appropriate carriers. Second, miRNAs must be protected from circulating RNAses and transferred to targeted or receptor-specific recipient cells. Finally and most importantly, miRNAs must retain the ability to recognize and repress mRNA targets in recipient cells [45].

\section{miRNA sorting into exosomes}

Exosome biogenesis [34,46], material cargo sorting $[46,47]$, and release [48] involve the endosomal sorting complex required for transport (ESCRT complex), acting together with associated proteins. The ESCRT complex recognizes ubiquitinated membrane proteins and promotes their internalization into the MVBs [49]. The lipid content of exosomes appears also to play an important role in both the packaging of exosomes and their delivery to downstream tissues. The tetraspanin family of proteins, which appears specifically enriched in exosomes among extracellular vesicles, has a high affinity for both sphingolipids and cholesterol, and brings along these lipid molecules during exosome packaging [28,50]. The miRNA maturation process seems to be associated to the formation and maturation of exosomes. Whether packing of miRNAs into exosomes takes place at the pre- or mature-miRNA level has to be yet fully understood. Some authors reported that sequence motifs present in mature miRNAs are able to control their 
sorting into exosomes. The ubiquitous heterogeneous nuclear ribonucleoprotein A2B1 (hnRNPA2B1) recognizing these motifs specifically binds exosomal miRNAs and controls their loading into exosomes [51].

It has been suggested that sorting of pre-miRNAs into exosomes could also be occurring in a sequencedependent manner and, indeed, pre-miRNA as well as mature miRNAs are found in exosomes (Figure 1; [52-55]). A very interesting work has recently revealed that breast cancer exosomes, differently from normal cell-derived exosomes, contain pre-miRNAs along with the core RNA-induced silencing complex (RISC) proteins, namely Dicer, Ago2 and TRBP, and display cellindependent capacity to process pre-miRNAs into mature miRNAs (Figure 1; [56]). In addition to miRNAs, exosomes carry mRNAs [25], which also show a selective enrichment [24]. Exosomes content in mRNAs seems to be enriched in 3'UTR fragments [18], and this might be important for the sorting of specific mRNAs into these vesicles [57].

Recently, it has been shown that miRNA availability for exosomal secretion is controlled, at least in part, by the cellular levels of their targeted transcripts, implying that exosomal miRNA secretion is a mechanism whereby cells rapidly dispose miRNAs in excess of their targets to adjust miRNA:mRNA homeostasis [58]. While these findings suggest that miRNA sorting may be a passive mechanism, increasing data indicate that exosomes can be actively internalized by recipient cells, resulting in miRNA transfer among cells of both homo- and heterotypic nature [21,24,25,59-61].

\section{Exosomal miRNAs in cell-to-cell communication}

The fact that exosomes are protected from the environment by their lipid bilayer makes them ideal delivery vehicles for RNAs [62]. In fact, exosomal miRNAs are more stable and resistant to degradation than cellular miRNAs [63]. In addition, exosomes can deliver multiple messages simultaneously, which make them an attractive way of exchanging specific subsets of mRNA, miRNA, or proteins between donor and recipient cells, also at a distance.

The modality of interaction of exosomes with selected target cells is still unclear. Both direct and indirect evidences exist to suggest that EVs are internalized into recipient cells, the first relying on the use of exosome fluorescent labeling, the second based on the transfer of functional miRNAs on target cells [64]. Exosomes display exquisite target cell selectivity in vitro and in vivo, which is based, at least in part, on target cell ligand interactions with exosomal tetraspanin-associated receptors. Maintenance of internalization complexes and reuse of these complexes for exosome uptake appear to be a common theme $[65,66]$. Importantly, the engagement of protein complexes in internalization prone membrane domains provides an explanation for the target cell selectivity that is difficult to imagine relying exclusively on single adhesion molecules, which frequently are expressed on many cells [67]. The binding of exosomes to the surface of recipient cells is mediated by the classical adhesion molecules involved in cell-cell interactions, such as integrins and ICAMs. However, other

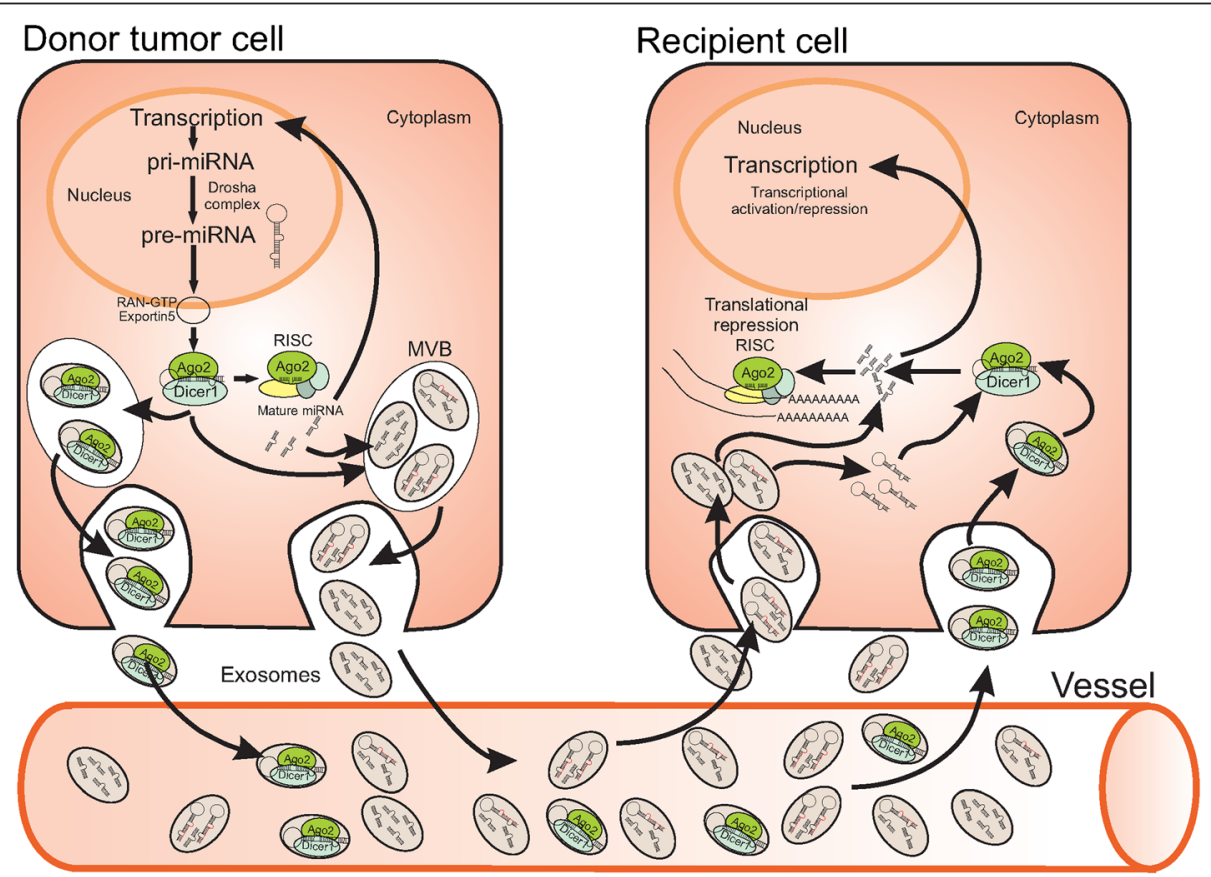

Figure 1 Schematic representation of miRNA sorting into tumor cell-derived exosomes and release to recipient cells. 
molecular pairs more specific to the exosome membrane, such as TIM-binding phosphatidylserines, carbohydrate/ lectin receptors and heparan sulfateproteoglycans (HSPGs), could be involved as well [67]. To deliver their content, exosomes attached to a recipient cell can either fuse with the cell membrane, directly releasing their cargo into the cytoplasm, or get internalized by endocytic pathways. Depending in the phagocytic and endocytic capacity of the recipient cells, exosomes can be internalized by clathrindynamin-caveolae-dependent endocytosis, pinocytosis, or phagocytosis [67].

Accumulating evidences from the literature support the idea that exosomal miRNAs can act as regulators of gene expression in distant cells. Particularly in cancer, exosomes have multiple functions including promotion of local and systemic processes that lead to cell growth and dissemination, or impairment of the immune system response. miRNAs can act either as tumor suppressors or oncogenes (oncomiRs), depending on target genes and cancer types. Furthermore, a particular miRNA can exploit both tumor-suppressive and oncogenic functions depending on the cellular context of its target genes in different cancers [68].

Table 1 and Figure 2 epitomize most significant exosomal miRNAs in cancer.

\section{Functions of exosomal miRNAs in cancer}

Exosomes have been found to act as vehicles for suppressive signals and have suppressive effects on antitumor immune responses [35,69]. For instance, miR-9 that is over-expressed in many cancers is able of inhibiting the transcription of the MHC class I gene thus preventing the recognition of tumor cells by the patient immune system [70]. Yet, miR-222 down-regulates the expression on tumor cell surfaces of intracellular cell adhesion molecule 1 (ICAM-1) whose binding to lymphocyte function-associated antigen (LFA-1) is essential for optimal activation of cytotoxic $\mathrm{T}$ cells, which in turn mediate tumor cell lysis [71].

In some cases, exosomal pathways might discard tumor-suppressor miRNAs that restrict metastatic progression. For example, the let-7 miRNA family was shown to be expressed at higher levels in exosomes derived from metastatic gastric cancer cells, compared to non-metastatic parental cells, suggesting that the exosomal mechanism may be used by metastatic cells to eliminate miRNAs having tumor suppressive functions, thus strengthening their aggressive behavior [72]. Another example comes from a recent paper showing that metastatic cells from bladder carcinoma secrete increased levels of miRNAs with tumor-suppressor functions (e.g. inhibition of invasion, angiogenesis, and pulmonary metastasis), including miR-23b, miR-224, and miR-921. Moreover, miRNAs, such as miR-23b, highly exocytosed from metastatic cells were reduced in lymph node metastases compared with patient-matched primary tumors [73]. These results suggest that exosome-mediated secretion of tumor-suppressor miRNAs is selected during tumor progression as a mechanism to coordinate activation of a metastatic cascade. An alternative hypothesis has been proposed to justify the relative abundance of miRNAs with predominant tumor suppressor activity in the blood of healthy individuals. According to this hypothesis, tumor-suppressor circulating miRNAs might work as a surveillance mechanism exerting continuous inhibition on tumor formation, complementing cancer immune surveillance [74]. It should be noted, however, that, in other instances, miR-23b may act as tumor promoting [75].

However, most literature reports a tumor promoting role of exosomal miRNAs, likely because tumor suppressor miRNAs are downregulated in many tumors, as well as in cancer stem cells. Many oncomiRs have been described in the past decade. For example, IL-4 activated macrophages have been shown to regulate invasiveness of breast cancer cells through exosome-mediated delivery of the miR-223 highlighting a novel communication mechanism between tumor-associated macrophages and cancer cells [76]. miR-21 has been found up-regulated in a wide range of solid tumors [77,78], and secreted in plasma exosomes from patients affected by different cancer types, such as ovarian, lung and colon carcinomas, pancreatic cancer and others, its presence being always positively correlated with tumor progression and aggressiveness [79-82]. Up-regulation of miR-21 was shown to promote cellular proliferation, survival, invasion and migration in different cancer cell lines [83], while its knockdown decreased tumor cell survival in vitro and tumor growth in vivo in a murine xenograft model, accompanied by enhanced apoptosis [84]. Interestingly, miR-21 and -29a secreted by tumor cells via exosomes have been shown to bind to toll-like receptors (TRL) on immune cells, leading to TLR-mediated NF-kB (nuclear factor kappa-light-chainenhancer of activated B cells) activation and secretion of prometastatic inflammatory cytokines that may ultimately lead to tumor growth and metastasis [85].

It is becoming clear that tumor released exosomes contribute to both progression of primary tumors and metastases. The central role of exosomes in tumor promotion has been recently highlighted by the discovery that breast cancer exosomes can perform cell-independent miRNA biogenesis and stimulate non-tumorigenic epithelial cells to form tumors, by altering their transcriptome in a Dicer-dependent manner [56]. The metastatic process involves the manipulation of the cellular microenvironment to optimize conditions for deposition and growth both locally and at a distance for tumor colonization $[86,87]$. 
Table 1 Most relevant miRNAs in cancer

\begin{tabular}{|c|c|c|c|c|}
\hline miRNA & Tumor & Main target genes & Function & Reference \\
\hline miR-15a & Multiple Myeloma & $\begin{array}{l}\text { BCL2, MYB, MYC, KRAS, CCND1, CDC25A, } \\
\text { ERBB2, TP53, PTEN, ITGA2, VEGFA,RAB21, } \\
\text { CADM1, DICER1 }\end{array}$ & $\begin{array}{l}\text { Oncogene Inhibition, Cell Cycle } \\
\text { Control, Inhibition of Angiogenesis }\end{array}$ & [97-100] \\
\hline miR-34a & $\begin{array}{l}\text { Breast, Prostate, Bladder, and } \\
\text { Brain Cancer }\end{array}$ & $\begin{array}{l}\text { BCL2, MYC, MET, MEK1, E2F3, CDK4, } \\
\text { CDK6, CD44 }\end{array}$ & $\begin{array}{l}\text { Cell Cycle Control, Apoptosis, } \\
\text { Senescence, Angiogenesis }\end{array}$ & {$[116,117,118]$} \\
\hline let-7 family & $\begin{array}{l}\text { Breast, Colon, Gastric, Liver, Lung, } \\
\text { Prostate, Ovarian Cancer, Chronic } \\
\text { Myelogenous Leukemia, B Cell } \\
\text { Lymphoma }\end{array}$ & $\begin{array}{l}\text { NF2, HRAS, KRAS, NRAS, LIN28, MYC, } \\
\text { DICER1, HMGA2, CASP3 }\end{array}$ & $\begin{array}{l}\text { Oncogene Inhibition, Cell Cycle } \\
\text { Control, Cancer Stem Cell } \\
\text { Regulation }\end{array}$ & {$[72,119-124,125]$} \\
\hline miR-21 & $\begin{array}{l}\text { Ovarian, Lung, and Colon Carcinoma, } \\
\text { Pancreatic and Breast Cancer }\end{array}$ & $\begin{array}{l}\text { TPM1, NFIB, PDCD4, CDKN1A, FAS, } \\
\text { TIMP3, SOX5, PTEN, BMPR2 }\end{array}$ & $\begin{array}{l}\text { Promotion of Cancer Cell } \\
\text { Proliferation, Survival and } \\
\text { Migration }\end{array}$ & {$[79-83,126-128]$} \\
\hline miR-17-92 cluster & Leukemia & $\begin{array}{l}\text { DICER, PTEN, E2F1, E2F2, E2F3, CDKN1A, } \\
\text { PTEN, BCL2, CCND1, BMPR2, HOXA9 }\end{array}$ & $\begin{array}{l}\text { Induction of Angiogenesis, } \\
\text { Enhance Endothelial Cell } \\
\text { Migration }\end{array}$ & {$[94,129]$} \\
\hline miR-494 & $\begin{array}{l}\text { Small Cell Lung Carcinoma, } \\
\text { Breast Cancer }\end{array}$ & PTEN, CDH17, MAL & $\begin{array}{l}\text { Inhibition of Apoptosis, } \\
\text { Induction of Chemoresistance, } \\
\text { Cell Adhesion }\end{array}$ & {$[89,130]$} \\
\hline miR-210 & $\begin{array}{l}\text { Breast Cancer, Renal, Prostate, and } \\
\text { Pancreatic Cancer, Lymphoma }\end{array}$ & $\begin{array}{l}\text { MYC, STAT5A, HIF1A, TP53, E2F3, VEGFA, } \\
\text { EGFR, CDKN1A, AKT1, DICER1, PTEN, } \\
\text { CDKN1B, ERBB2, CD40, BCL2, CASP8AP2, } \\
\text { KRAS, NOTCH1 }\end{array}$ & $\begin{array}{l}\text { Metastasis, Angiogenesis, } \\
\text { Hypoxia, Tumorigenesis }\end{array}$ & {$[7,96,131-133]$} \\
\hline miR-200 family & Breast Cancer & $\begin{array}{l}\text { ZEB1, ZEB2, SIP1, CCND1, CDC25C, MYC, } \\
\text { MYCN, PTEN, SIRT1, VEGFA, MET, } \\
\text { CDKN1B, TP53, PROM1, EGFR, CD44 }\end{array}$ & $\begin{array}{l}\text { Tumorigenesis and Tumor } \\
\text { Progression, Metastasis, Invasion }\end{array}$ & {$[92,93]$} \\
\hline miR-9 & $\begin{array}{l}\text { Melanoma, Glioblastoma, } \\
\text { Neuroblastoma }\end{array}$ & MYC, MYCN,VEGFA, MMP9, CDH1 & $\begin{array}{l}\text { Metastasis, Drug Resistance, } \\
\text { Angiogenesis }\end{array}$ & {$[95,110,134,135]$} \\
\hline miR-221/miR-222 & $\begin{array}{l}\text { Breast, Colorectal, Renal, Pancreatic, } \\
\text { and Ovarian Cancer, Melanoma, } \\
\text { Glioblastoma, Leukemia }\end{array}$ & $\begin{array}{l}\text { KIT, PTEN, CDKN1A, CDKN1B, KRAS, } \\
\text { DICER1, MMP1 }\end{array}$ & $\begin{array}{l}\text { Drug Resistance, Metastasis, } \\
\text { Invasion, Cell Growth }\end{array}$ & {$[108,136-143]$} \\
\hline miR-23b & $\begin{array}{l}\text { Breast, Renal, Pancreatic, Bladder, } \\
\text { and Prostate Cancer Thymic } \\
\text { Lymphoma }\end{array}$ & $\begin{array}{l}\text { VHL, PTEN, FAS, NISCARI, PAK2, ATG12, } \\
\text { ZEB1, SRC, AKT }\end{array}$ & $\begin{array}{l}\text { Cell Proliferation, Chemoresistance, } \\
\text { Inhibition of Invasion and } \\
\text { Angiogenesis }\end{array}$ & {$[73,75]$} \\
\hline miR-542-3p & $\begin{array}{l}\text { Pancreatic, and Cervical Carcinoma, } \\
\text { Neuroblastoma, Colon Cancer }\end{array}$ & CDH17, TRAF4, ANGPT2, ILK, SURVIVIN & $\begin{array}{l}\text { Decreased Cell Adhesion, } \\
\text { Induction of Apoptosis, } \\
\text { Inhibition of Proliferation } \\
\text { and Angiogenesis }\end{array}$ & {$[89,144,145]$} \\
\hline miR-125b & Breast, and Liver Cancer & LIN28B, CCND1, SOX2, MYC, CDK6, & $\begin{array}{l}\text { Increase Drug Resistance, } \\
\text { Decreased in Resistant Cells, } \\
\text { Inhibits Cell Proliferation }\end{array}$ & [146-149] \\
\hline miR-105 & $\begin{array}{l}\text { Breast, Ovarian, Gastric, and Prostate } \\
\text { Cancer, Glioma, Hepatocellular } \\
\text { Carcinoma }\end{array}$ & TJP1 DNTT, PCNA, BAX, CCND1, CDK6 & $\begin{array}{l}\text { Regulation of Migration, } \\
\text { Metastasis, Proliferation, } \\
\text { Apoptosis }\end{array}$ & {$[91,150-153]$} \\
\hline miR-29 & $\begin{array}{l}\text { Breast, Lung, and Cervical Cancer, } \\
\text { Neuroblastoma, B Cell Chronic and } \\
\text { Acute Myeloid Leukemia }\end{array}$ & $\begin{array}{l}\text { BACE1, DNMT3A, DNMT3B, CDC42, } \\
\text { CDK6, TGFB3, IFNG }\end{array}$ & $\begin{array}{l}\text { Modulation of Immune } \\
\text { Response, Tumor Growth and } \\
\text { Metastasis, Tumor Suppressor } \\
\text { Function }\end{array}$ & {$[85,154-156]$} \\
\hline
\end{tabular}

It was recently reported that melanoma exosomes can modify distant lymph nodes to facilitate melanoma growth and metastasis even in the local absence of tumor cells [88]. Exosomal miRNAs derived from metastatic adenocarcinoma cells were also involved in modulation of premetastatic organ stroma cells toward supporting tumor cell hosting. Exosomal mRNAs and miRNAs derived from tumor cells were recovered in lymph node stroma and lung fibroblasts, and were shown to significantly affect mRNA translation in the target cells, exemplified by abundant recovery of exosomal miR-494 and miR-542-3p, which targeted cadherin17 [89]. In addition to modulation of stromal cells, recent data have also demonstrated a pivotal role for cancer cell-derived exosomes in the organization of the extracellular matrix (ECM). Being rich in proteases, 


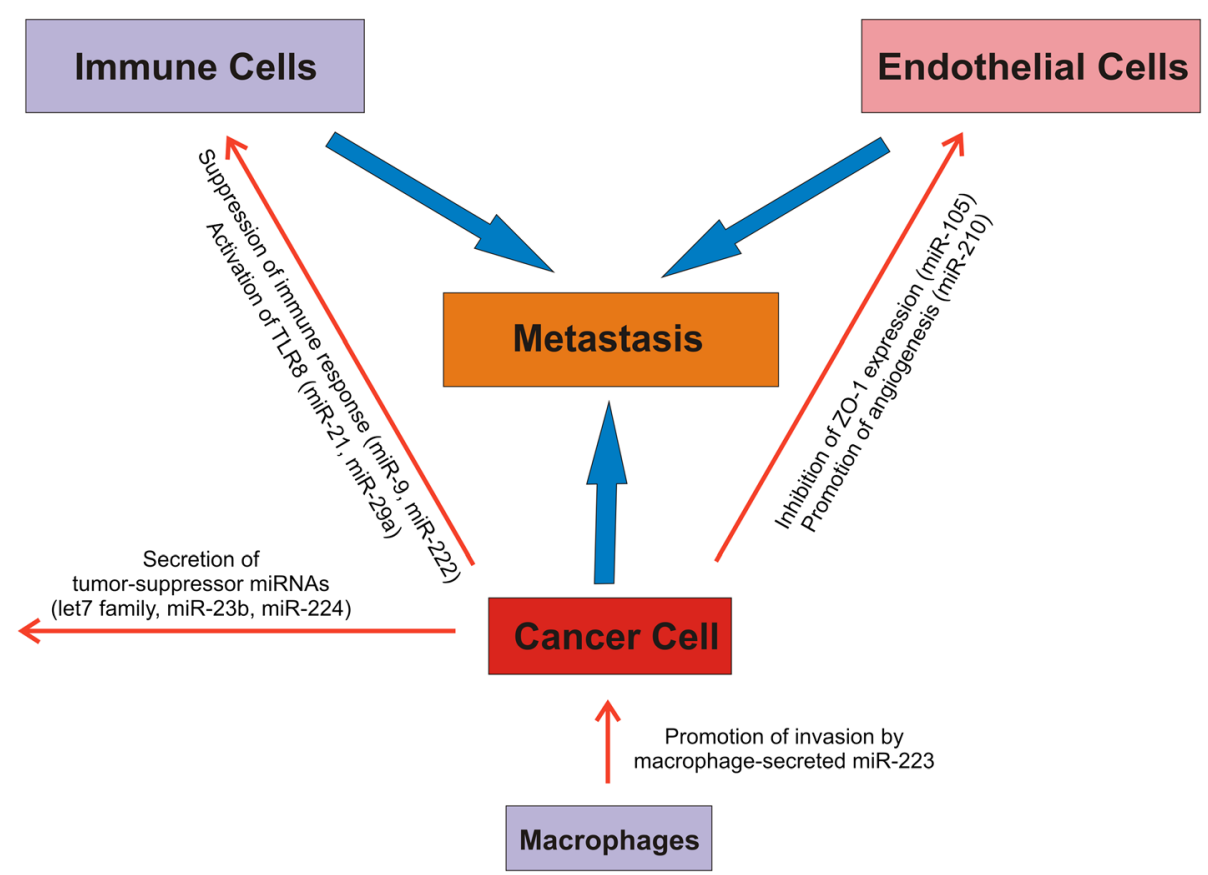

Figure 2 Cancer cell-secreted exosomal miRNAs contribute to the formation of the metastatic niche.

exosomes can modulate the ECM for degradation of collagens, laminin, and fibronectin, and this may have severe consequences on tumor and host cell adhesion, motility, and invasiveness [90].

Exosomal miRNAs can also participate in cancer metastasis by adapting the tumor niche cells. miR-105, which is characteristically expressed and secreted by metastatic breast cancer cells, is a potent regulator of migration through targeting the tight junction protein ZO-1. In endothelial monolayers, exosome-mediated transfer of cancer-secreted miR-105 efficiently destroys tight junctions and the integrity of these natural barriers against metastasis. Overexpression of miR-105 in nonmetastatic cancer cells induces metastasis and vascular permeability in distant organs, whereas inhibition of miR-105 in highly metastatic tumors alleviates these effects [91]. It has been recently shown that miR-200 family members, which regulates the mesenchymal-toepithelial transition, within extracellular vesicles secreted from highly metastatic tumor cells can be internalized by weakly metastatic cells and confer the capability of tumor growth at metastatic lesions [92,93].

The contribution of exosome in induction of angiogenesis to promote cancer metastasis is also described. For instance, it was shown that miRNA-enriched exosomes released by CD105 cancer stem cells from renal carcinomas may modify the tumor microenvironment by triggering angiogenesis and may promote formation of a pre-metastatic niche [42]. Specific exosomal miRNAs, such as those of the miR-17-92 cluster, have an important role in neoplasia-to-endothelial cell communication for regulating endothelial gene expression during tumor angiogenesis in leukemia cells [94]. It was also shown that tumor-secreted miR-9 encapsulated into microvesicles promotes endothelial cell migration and tumour angiogenesis participating in intercellular communication and function [95]. Moreover, exosomal angiogenic miR-210, known to be increased in the serum of cancer patients with malignant breast cancer, regulate the metastatic ability of cancer cells through suppression of specific target genes, which resulted in enhanced angiogenesis [96]. In addition, neutral sphyngomyelinase 2 (nSMase2) was required to regulate exosomal miRNA secretion from cancer cells and promote angiogenesis within the tumor microenvironment as well as metastasis [96]. These findings suggest that the horizontal transfer of exosomal miRNAs from cancer cells can dictate the microenviromental niche for the benefit of cancer progression. Some studies also suggest that the microenvironment may play a crucial role in regulating the pathogenesis of some tumors by modulating the expression of exosomal miRNAs. Bone marrow stromal cells modulate miR-15a, which act as putative tumor suppressor in multiple myeloma cells thus facilitating the progression of this tumor [97-100].

The exosomal miRNA profiling of sera from cancer patients versus healthy individuals has often revealed important differences in relation to tumor progression, 
highlighting a possible use of these miRNAs as disease prognostic biomarkers $[101,102]$. In addition, many tumors displaying drug resistance show alterations in the expression of miRNAs. The up- or down-regulation of miRNAs affects the expression of several target proteins (drug targets, transporters, cell cycle- and apoptosisrelated components, key signaling pathway components involved in drug response), determining changes in drug sensitivity through different molecular mechanisms $[103,104]$. Moreover, different studies indicate that exosomes act as vehicles for exchange of genetic cargo between heterogeneous populations of tumor cells, generating a way of transmitting drug resistance [105-107]. Recently Chen and colleagues reported that exosomes from drug resistant breast cancer cells are capable of delivering a subset of miRNAs (miR-100, miR-222 and miR-30a) to sensitive cells [108]. miR-34a, detected as both intracellular and exosomal biomarker, was recently found also to influence prostate cancer cell response to docetaxel by regulating anti-apoptotic BCL-2 gene [109]. In addition, the inhibition of miR-9 expression in chemoresistant glioblastoma multiforme (GBM) cells, by transferring to GBM cells miR-9 microvesiclesencapsulated inhibitors, resulted in reversed expression of the multidrug transporter and sensitized GBM cells to the treatments [110].

\section{Conclusions}

Intensive research effort is spent to find out new cancer diagnostic and prognostic tools. Representing a noninvasive approach, measurement of extracellular miRNAs in biological fluids might prove a valuable strategy. In addition, since dysregulation of miRNAs is fundamental to the pathogenesis of many cancers, they are attractive candidates for clinical application as therapeutic targets in both solid and hematological malignancies [111]. Down-regulation of target oncogenes by reexpression of tumor suppressor miRNAs, or re-expression of tumor suppressor genes by silencing oncomiRs is expected to impair tumor growth and metastasis [112]. Noteworthy, miR-34 mimic has become the first cancertargeted miRNA drug (MRX34) entering Phase I clinical trials (ClinicalTrials.govidentifier: NCT01829971) in patients with advanced hepatocellular carcinoma [113]. A new class of drugs that specifically target miRNA pathways are being currently developed. They work either via replacement of tumor suppressed miRNAs with synthetic or viral vector encoded miRNA mimics, or via antisensemediated inhibition of oncogenic miRNAs. However, offtarget effects must be evaluated before such therapies can be safely applied to the clinic. Recently, a novel system for miRNA or antagomiR delivery applicable for both local and systemic administration with the use of mesenchymal stem cell microparticles was developed in in vitro models
$[110,114,115]$. The use of miRNA-containing exosomes as cancer prognostic biomarkers and vehicles for miRNAbased therapy could be feasible and easily exploitable in clinical practice, with the goal of developing a personalized anticancer therapy.

\section{Competing interests}

The authors declare that they have no competing interests.

\section{Authors' contributions}

GF, AF and ID conceived the study. GF and ID searched the literature and drafted the manuscript. All the authors participated in the discussion, provided conceptual input, have read and approved the final manuscript.

\section{Acknowledgments}

The financial support of Telethon - Italy (Grant n. GGP14092 to G. Falcone) and of the Italian Ministry for Education, University and Research in the framework of the Flagship Project NanoMAX (to A. Felsani and I. D'Agnano) is gratefully acknowledged.

\section{Author details}

${ }^{1}$ Institute of Cell Biology and Neurobiology, CNR, Via Ramarini 32-00015, Monterotondo, RM, Italy. ${ }^{2}$ Genomnia srl, Via Nerviano, 31/B - 20020, Lainate, MI, Italy.

Received: 6 February 2015 Accepted: 16 March 2015

Published online: 02 April 2015

\section{References}

1. Ciesla M, Skrzypek K, Kozakowska M, Loboda A, Jozkowicz A, Dulak J. MicroRNAs as biomarkers of disease onset. Anal Bioanal Chem. 2011;401:2051-61.

2. Ma R, Jiang T, Kang X. Circulating microRNAs in cancer: origin, function and application. J Exp Clin Cancer Res. 2012:31:38.

3. Liang H, Zhang J, Zen K, Zhang CY, Chen X. Nuclear microRNAs and their unconventional role in regulating non-coding RNAs. Protein Cell. 2013;4:325-30

4. Liu J, Zheng $M$, Tang $Y L$, Liang $X H$, Yang Q. MicroRNAs, an active and versatile group in cancers. Int J Oral Sci. 2011;3:165-75.

5. Chen X, Ba Y, Ma L, Cai X, Yin Y, Wang K, et al. Characterization of microRNAs in serum: a novel class of biomarkers for diagnosis of cancer and other diseases. Cell Res. 2008;18:997-1006

6. Chim SS, Shing TK, Hung EC, Leung TY, Lau TK, Chiu RW, et al. Detection and characterization of placental microRNAs in maternal plasma. Clin Chem. 2008:54:482-90.

7. Lawrie CH, Gal S, Dunlop HM, Pushkaran B, Liggins AP, Pulford K, et al. Detection of elevated levels of tumour-associated microRNAs in serum of patients with diffuse large B-cell lymphoma. $\mathrm{Br} J$ Haematol. 2008;141:672-5

8. Mitchell PS, Parkin RK, Kroh EM, Fritz BR, Wyman SK, Pogosova-Agadjanyan EL, et al. Circulating microRNAs as stable blood-based markers for cancer detection. Proc Natl Acad Sci U S A. 2008;105:10513-8.

9. Hanke M, Hoefig K, Merz H, Feller AC, Kausch I, Jocham D, et al. A robust methodology to study urine microRNA as tumor marker: microRNA-126 and microRNA-182 are related to urinary bladder cancer. Urol Oncol. 2010;28:655-61.

10. Kosaka N, Izumi H, Sekine K, Ochiya T. microRNA as a new immuneregulatory agent in breast milk. Silence. 2010;1:7.

11. Park NJ, Zhou H, Elashoff D, Henson BS, Kastratovic DA, Abemayor E, et al. Salivary microRNA: discovery, characterization, and clinical utility for oral cancer detection. Clin Cancer Res. 2009;15:5473-7.

12. Weber JA, Baxter DH, Zhang S, Huang DY, Huang KH, Lee MJ, et al. The microRNA spectrum in 12 body fluids. Clin Chem. 2010;56:1733-41.

13. Chen $X$, Liang $H$, Zhang J, Zen K, Zhang CY. Secreted microRNAs: a new form of intercellular communication. Trends Cell Biol. 2012;22:125-32.

14. Cortez MA, Bueso-Ramos C, Ferdin J, Lopez-Berestein G, Sood AK, Calin GA MicroRNAs in body fluids-the mix of hormones and biomarkers. Nat Rev Clin Oncol. 2011;8:467-77.

15. Turchinovich A, Burwinkel B. Distinct AGO1 and AGO2 associated miRNA profiles in human cells and blood plasma. RNABiol. 2012;9:1066-75. 
16. Arroyo JD, Chevillet JR, Kroh EM, Ruf IK, Pritchard CC, Gibson DF, et al. Argonaute2 complexes carry a population of circulating microRNAs independent of vesicles in human plasma. Proc Natl Acad Sci U S A. 2011;108:5003-8.

17. Turchinovich A, Weiz L, Langheinz A, Burwinkel B. Characterization of extracellular circulating microRNA. Nucleic Acids Res. 2011;39:7223-33.

18. Vickers KC, Palmisano BT, Shoucri BM, Shamburek RD, Remaley AT. MicroRNAs are transported in plasma and delivered to recipient cells by high-density lipoproteins. Nat Cell Biol. 2011;13:423-33.

19. Wagner J, Riwanto M, Besler C, Knau A, Fichtlscherer S, Roxe T, et al. Characterization of levels and cellular transfer of circulating lipoproteinbound microRNAs. Arterioscler Thromb Vasc Biol. 2013;33:1392-400.

20. Kosaka N, Iguchi H, Yoshioka Y, Takeshita F, Matsuki Y, Ochiya T. Secretory mechanisms and intercellular transfer of microRNAs in living cells. J Biol Chem. 2010;285:17442-52.

21. Mittelbrunn M, Gutierrez-Vazquez C, Villarroya-Beltri C, Gonzalez S, SanchezCabo F, Gonzalez MA, et al. Unidirectional transfer of microRNA-loaded exosomes from $T$ cells to antigen-presenting cells. Nat Commun. 2011;2:282.

22. Montecalvo A, Larregina AT, Shufesky WJ, Stolz DB, Sullivan ML, Karlsson JM, et al. Mechanism of transfer of functional microRNAs between mouse dendritic cells via exosomes. Blood. 2012;119:756-66.

23. Pegtel DM, Cosmopoulos K, Thorley-Lawson DA, van Eijndhoven MA, Hopmans ES, Lindenberg $J$, et al. Functional delivery of viral miRNAs via exosomes. Proc Natl Acad Sci U S A. 2010;107:6328-33.

24. Skog J, Wurdinger T, van Rijn S, Meijer DH, Gainche L, Sena-Esteves M, et al. Glioblastoma microvesicles transport RNA and proteins that promote tumour growth and provide diagnostic biomarkers. Nat Cell Biol. 2008;10:1470-6.

25. Valadi H, Ekstrom K, Bossios A, Sjostrand M, Lee JJ, Lotvall JO. Exosomemediated transfer of mRNAs and microRNAs is a novel mechanism of genetic exchange between cells. Nat Cell Biol. 2007;9:654-9.

26. Thery C, Zitvogel L, Amigorena S. Exosomes: composition, biogenesis and function. Nat Rev Immunol. 2002;2:569-79.

27. Yuana Y, Sturk A, Nieuwland R. Extracellular vesicles in physiological and pathological conditions. Blood Rev. 2013;27:31-9.

28. Trajkovic K, Hsu C, Chiantia S, Rajendran L, Wenzel D, Wieland F, et al. Ceramide triggers budding of exosome vesicles into multivesicular endosomes. Science. 2008;319:1244-7.

29. Gutierrez-Vazquez C, Villarroya-Beltri C, Mittelbrunn M, Sanchez-Madrid F. Transfer of extracellular vesicles during immune cell-cell interactions. Immunol Rev. 2013:251:125-42.

30. Villarroya-Beltri C, Baixauli F, Gutierrez-Vazquez C, Sanchez-Madrid F, Mittelbrunn M. Sorting it out: regulation of exosome loading. Semin Cancer Biol. 2014;28:3-13.

31. Nolte-'t Hoen EN, Buermans HP, Waasdorp M, Stoorvogel W, Wauben MH 't Hoen PA. Deep sequencing of RNA from immune cell-derived vesicles uncovers the selective incorporation of small non-coding RNA biotypes with potential regulatory functions. Nucleic Acids Res. 2012;40:9272-85.

32. Balaj L, Lessard R, Dai L, Cho YJ, Pomeroy SL, Breakefield XO, et al. Tumour microvesicles contain retrotransposon elements and amplified oncogene sequences. Nat Commun. 2011;2:180.

33. Thakur BK, Zhang H, Becker A, Matei I, Huang Y, Costa-Silva B, et al. Doublestranded DNA in exosomes: a novel biomarker in cancer detection. Cell Res. 2014:24:766-9.

34. Mayers JR, Audhya A. Vesicle formation within endosomes: An ESCRT marks the spot. Commun Integr Biol. 2012;5:50-6.

35. Taylor DD, Gercel-Taylor C. Exosomes/microvesicles: mediators of cancerassociated immunosuppressive microenvironments. Semin Immunopathol. 2011;33:441-54

36. Ji H, Chen M, Greening DW, He W, Rai A, Zhang W, et al. Deep sequencing of RNA from three different extracellular vesicle (EV) subtypes released from the human LIM1863 colon cancer cell line uncovers distinct miRNA-enrichment signatures. PLoSOne. 2014;9:e110314.

37. Andreola G, Rivoltini L, Castelli C, Huber V, Perego P, Deho P, et al. Induction of lymphocyte apoptosis by tumor cell secretion of FasL-bearing microvesicles. J Exp Med. 2002;195:1303-16.

38. Chalmin F, Ladoire S, Mignot G, Vincent J, Bruchard M, Remy-Martin JP, et al. Membrane-associated Hsp72 from tumor-derived exosomes mediates STAT3-dependent immunosuppressive function of mouse and human myeloid-derived suppressor cells. J Clin Invest. 2010;120:457-71.
39. Clayton A, Mitchell JP, Court J, Linnane S, Mason MD, Tabi Z. Human tumor-derived exosomes down-modulate NKG2D expression. J Immunol. 2008;180:7249-58

40. Szajnik M, Czystowska M, Szczepanski MJ, Mandapathil M, Whiteside TL. Tumor-derived microvesicles induce, expand and up-regulate biological activities of human regulatory T cells (Treg). PLoSOne. 2010;5:e11469.

41. Wieckowski EU, Visus C, Szajnik M, Szczepanski MJ, Storkus WJ, Whiteside TL. Tumor-derived microvesicles promote regulatory $T$ cell expansion and induce apoptosis in tumor-reactive activated CD8+ T lymphocytes. J Immunol. 2009:183:3720-30.

42. Grange C, Tapparo M, Collino F, Vitillo L, Damasco C, Deregibus MC, et al. Microvesicles released from human renal cancer stem cells stimulate angiogenesis and formation of lung premetastatic niche. Cancer Res. 2011;71:5346-56

43. Peinado H, Aleckovic M, Lavotshkin S, Matei I, Costa-Silva B, Moreno-Bueno G, et al. Melanoma exosomes educate bone marrow progenitor cells toward a pro-metastatic phenotype through MET. Nat Med. 2012;18:883-91.

44. Taverna S, Amodeo V, Saieva L, Russo A, Giallombardo M, De Leo G, et al. Exosomal shuttling of miR-126 in endothelial cells modulates adhesive and migratory abilities of chronic myelogenous leukemia cells. Mol Cancer. 2014;13:169.

45. Salido-Guadarrama I, Romero-Cordoba S, Peralta-Zaragoza O, HidalgoMiranda A, Rodriguez-Dorantes M. MicroRNAs transported by exosomes in body fluids as mediators of intercellular communication in cancer. Onco Targets Ther. 2014;7:1327-38.

46. El Lee Y, Andaloussi S, Wood MJ. Exosomes and microvesicles: extracellular vesicles for genetic information transfer and gene therapy. Hum Mol Genet. 2012;21:R125-34

47. Raiborg C, Stenmark H. The ESCRT machinery in endosomal sorting of ubiquitylated membrane proteins. Nature. 2009;458:445-52.

48. Tamai K, Tanaka N, Nakano T, Kakazu E, Kondo Y, Inoue J, et al. Exosome secretion of dendritic cells is regulated by Hrs, an ESCRT-0 protein. Biochem Biophys Res Commun. 2010;399:384-90.

49. Wollert T, Hurley JH. Molecular mechanism of multivesicular body biogenesis by ESCRT complexes. Nature. 2010;464:864-9.

50. Rayner KJ, Hennessy EJ. Extracellular communication via microRNA: lipid particles have a new message. J Lipid Res. 2013;54:1174-81.

51. Villarroya-Beltri C, Gutierrez-Vazquez C, Sanchez-Cabo F, Perez-Hernandez D, Vazquez J, Martin-Cofreces N, et al. Sumoylated hnRNPA2B1 controls the sorting of miRNAs into exosomes through binding to specific motifs. Nat Commun. 2013:4:2980.

52. Chen TS, Lai RC, Lee MM, Choo AB, Lee CN, Lim SK. Mesenchymal stem cell secretes microparticles enriched in pre-microRNAs. Nucleic Acids Res. 2010;38:215-24.

53. Li L, Zhu D, Huang L, Zhang J, Bian Z, Chen X, et al. Argonaute 2 complexes selectively protect the circulating microRNAs in cell-secreted microvesicles. PLoSOne. 2012;7:e46957.

54. Pigati L, Yaddanapudi SC, lyengar R, Kim DJ, Hearn SA, Danforth D, et al. Selective release of microRNA species from normal and malignant mammary epithelial cells. PLoSOne. 2010;5:e13515.

55. Zhou Q, Li M, Wang X, Li Q, Wang T, Zhu Q, et al. Immune-related microRNAs are abundant in breast milk exosomes. Int J Biol Sci. 2012;8:118-23.

56. Melo SA, Sugimoto H, O'Connell T, Noritoshi K, Villanueva A, Vidal A, et al. Cancer Exosomes Perform Cell-Independent MicroRNA Biogenesis and Promote Tumorigenesis. Cancer Cell. 2014;26:707-21.

57. Bolukbasi MF, Mizrak A, Ozdener GB, Madlener S, Strobel T, Erkan EP, et al. miR-1289 and "Zipcode"-like Sequence Enrich mRNAs in Microvesicles. MolTherNucleic Acids. 2012;1:e10.

58. Squadrito ML, Baer C, Burdet F, Maderna C, Gilfillan GD, Lyle R, et al. Endogenous RNAs modulate microRNA sorting to exosomes and transfer to acceptor cells. Cell Rep. 2014;8:1432-46.

59. Hergenreider E, Heydt S, Treguer K, Boettger T, Horrevoets AJ, Zeiher AM, et al. Atheroprotective communication between endothelial cells and smooth muscle cells through miRNAs. Nat Cell Biol. 2012;14:249-56.

60. Ramachandran S, Palanisamy V. Horizontal transfer of RNAs: exosomes as mediators of intercellular communication. WileyInterdiscipRevRNA. 2012:3:286-93.

61. Simons M, Raposo G. Exosomes-vesicular carriers for intercellular communication. Curr Opin Cell Biol. 2009;21:575-81. 
62. Zomer A, Vendrig T, Hopmans ES, van Eijndhoven M, Middeldorp JM, Pegtel DM. Exosomes: Fit to deliver small RNA. Commun Integr Biol. 2010;3:447-50.

63. Hu G, Drescher KM, Chen XM. Exosomal miRNAs: Biological Properties and Therapeutic Potential. Front Genet. 2012;3:56.

64. Mulcahy LA, Pink RC, Carter DR. Routes and mechanisms of extracellular vesicle uptake. J Extracell Vesicles. 2014;3:24641.

65. Bauer M, Pelkmans L. A new paradigm for membrane-organizing and -shaping scaffolds. FEBS Lett. 2006;580:5559-64.

66. Mathivanan S, Ji H, Simpson RJ. Exosomes: extracellular organelles important in intercellular communication. J Proteomics. 2010;73:1907-20.

67. Thuma F, Zoller M. Outsmart tumor exosomes to steal the cancer initiating cell its niche. Semin Cancer Biol. 2014;28:39-50.

68. Chen PS, Su JL, Hung MC. Dysregulation of microRNAs in cancer. J Biomed Sci. 2012;19:90.

69. Filipazzi P, Burdek M, Villa A, Rivoltini L, Huber V. Recent advances on the role of tumor exosomes in immunosuppression and disease progression. Semin Cancer Biol. 2012;22:342-9.

70. Gao F, Zhao ZL, Zhao WT, Fan QR, Wang SC, Li J, et al. miR-9 modulates the expression of interferon-regulated genes and MHC class I molecules in human nasopharyngeal carcinoma cells. Biochem Biophys Res Commun. 2013:431:610-6.

71. Ueda R, Kohanbash G, Sasaki K, Fujita M, Zhu X, Kastenhuber ER, et al. Dicerregulated microRNAs 222 and 339 promote resistance of cancer cells to cytotoxic T-lymphocytes by down-regulation of ICAM-1. Proc Natl Acad Sci U S A. 2009;106:10746-51.

72. Ohshima K, Inoue K, Fujiwara A, Hatakeyama K, Kanto K, Watanabe Y, et al. Let-7 microRNA family is selectively secreted into the extracellular environment via exosomes in a metastatic gastric cancer cell line. PLoSOne. 2010;5:e13247.

73. Ostenfeld MS, Jeppesen DK, Laurberg JR, Boysen AT, Bramsen JB, PrimdalBengtson B, et al. Cellular Disposal of miR23b by RAB27-Dependent Exosome Release Is Linked to Acquisition of Metastatic Properties. Cancer Res. 2014;74:5758-71.

74. Igaz I, Igaz P. Tumor surveillance by circulating microRNAs: a hypothesis. Cell Mol Life Sci. 2014;71:4081-7.

75. Donadelli M, Dando I, Fiorini C, Palmieri M. Regulation of miR-23b expression and its dual role on ROS production and tumour development. Cancer Lett. 2014;349:107-13.

76. Yang M, Chen J, Su F, Yu B, Su F, Lin L, et al. Microvesicles secreted by macrophages shuttle invasion-potentiating microRNAs into breast cancer cells. Mol Cancer. 2011:10:117.

77. Volinia S, Calin GA, Liu CG, Ambs S, Cimmino A, Petrocca F, et al. A microRNA expression signature of human solid tumors defines cancer gene targets. Proc Natl Acad Sci U S A. 2006;103:2257-61.

78. Wang B, Zhang Q. The expression and clinical significance of circulating microRNA-21 in serum of five solid tumors. J Cancer Res Clin Oncol. 2012;138:1659-66.

79. Cappellesso R, Tinazzi A, Giurici T, Simonato F, Guzzardo V, Ventura L, et al. Programmed cell death 4 and microRNA 21 inverse expression is maintained in cells and exosomes from ovarian serous carcinoma effusions. Cancer Cytopathol. 2014;122:685-93.

80. Leidinger P, Backes C, Dahmke IN, Galata V, Huwer H, Stehle I, et al. What makes a blood cell based miRNA expression pattern disease specific? - A miRNome analysis of blood cell subsets in lung cancer patients and healthy controls. Oncotarget. 2014:5:9484-97.

81. Ogata-Kawata H, Izumiya M, Kurioka D, Honma Y, Yamada Y, Furuta K, et al. Circulating exosomal microRNAs as biomarkers of colon cancer. PLoSOne. 2014;9:e92921

82. Que R, Ding G, Chen J, Cao L. Analysis of serum exosomal microRNAs and clinicopathologic features of patients with pancreatic adenocarcinoma. World J Surg Oncol. 2013;11:219.

83. Lu Z, Liu M, Stribinskis V, Klinge CM, Ramos KS, Colburn NH, et al. MicroRNA-21 promotes cell transformation by targeting the programmed cell death 4 gene. Oncogene. 2008;27:4373-9.

84. Yan LX, Wu QN, Zhang Y, Li YY, Liao DZ, Hou JH, et al. Knockdown of miR-21 in human breast cancer cell lines inhibits proliferation, in vitro migration and in vivo tumor growth. Breast Cancer Res. 2011;13:R2.

85. Fabbri M, Paone A, Calore F, Galli R, Croce CM. A new role for microRNAs, as ligands of Toll-like receptors. RNABiol. 2013;10:169-74.
86. Mittelbrunn M, Sanchez-Madrid F. Intercellular communication: diverse structures for exchange of genetic information. Nat Rev Mol Cell Biol. 2012;13:328-35.

87. Shah MY, Calin GA. The mix of two worlds: non-coding RNAs and hormones Nucleic Acid Ther. 2013;23:2-8.

88. Hood JL, San RS, Wickline SA. Exosomes released by melanoma cells prepare sentinel lymph nodes for tumor metastasis. Cancer Res. 2011;71:3792-801.

89. Rana S, Malinowska K, Zoller M. Exosomal tumor microRNA modulates premetastatic organ cells. Neoplasia. 2013;15:281-95.

90. Mu W, Rana S, Zoller M. Host matrix modulation by tumor exosomes promotes motility and invasiveness. Neoplasia. 2013;15:875-87.

91. Zhou W, Fong MY, Min Y, Somlo G, Liu L, Palomares MR, et al. Cancersecreted miR-105 destroys vascular endothelial barriers to promote metastasis. Cancer Cell. 2014;25:501-15.

92. Epstein DM. Special delivery: microRNA-200-containing extracellular vesicles provide metastatic message to distal tumor cells. J Clin Invest. 2014;124:5107-8.

93. Le MT, Hamar P, Guo C, Basar E, Perdigao-Henriques R, Balaj L, et al. miR200-containing extracellular vesicles promote breast cancer cell metastasis. J Clin Invest. 2014;124:5109-28.

94. Umezu T, Ohyashiki K, Kuroda M, Ohyashiki JH. Leukemia cell to endothelial cell communication via exosomal miRNAs. Oncogene. 2013;32:2747-55.

95. Zhuang G, Wu X, Jiang Z, Kasman I, Yao J, Guan Y, et al. Tumour-secreted miR-9 promotes endothelial cell migration and angiogenesis by activating the JAK-STAT pathway. EMBO J. 2012;31:3513-23.

96. Kosaka N, Iguchi H, Hagiwara K, Yoshioka Y, Takeshita F, Ochiya T. Neutral sphingomyelinase 2 (nSMase2)-dependent exosomal transfer of angiogenic microRNAs regulate cancer cell metastasis. J Biol Chem. 2013;288:10849-59.

97. Abdi J, Qiu L, Chang H. Micro-RNAs, New performers in multiple myeloma bone marrow microenvironment. Biomark Res. 2014;2:10.

98. Gao X, Zhang R, Qu X, Zhao M, Zhang S, Wu H, et al. MiR-15a, miR-16-1 and miR-17-92 cluster expression are linked to poor prognosis in multiple myeloma. Leuk Res. 2012;36:1505-9.

99. Sun $C Y$, She $X M$, Qin $Y$, Chu ZB, Chen L, Ai LS, et al. miR-15a and miR-16 affect the angiogenesis of multiple myeloma by targeting VEGF. Carcinogenesis. 2013;34:426-35.

100. Roccaro AM, Sacco A, Maiso P, Azab AK, Tai YT, Reagan M, et al. BM mesenchymal stromal cell-derived exosomes facilitate multiple myeloma progression. J Clin Invest. 2013;123:1542-55.

101. Ye SB, Li ZL, Luo DH, Huang BJ, Chen YS, Zhang XS, et al. Tumor-derived exosomes promote tumor progression and T-cell dysfunction through the regulation of enriched exosomal microRNAs in human nasopharyngeal carcinoma. Oncotarget. 2014;5:5439-52.

102. Eichelser C, Stuckrath I, Muller V, Milde-Langosch K, Wikman H, Pantel K, et al. Increased serum levels of circulating exosomal microRNA-373 in receptor-negative breast cancer patients. Oncotarget. 2014;5:9650-63.

103. Migliore C, Giordano S. Resistance to targeted therapies: a role for microRNAs? Trends Mol Med. 2013;19:633-42.

104. Zheng T, Wang J, Chen X, Liu L. Role of microRNA in anticancer drug resistance. Int J Cancer. 2010;126:2-10.

105. Corcoran C, Rani S, O'Brien K, O'Neill A, Prencipe M, Sheikh R, et al. Docetaxel-resistance in prostate cancer: evaluating associated phenotypic changes and potential for resistance transfer via exosomes. PLoSOne. 2012:7:e50999.

106. O'Brien K, Rani S, Corcoran C, Wallace R, Hughes L, Friel AM, et al. Exosomes from triple-negative breast cancer cells can transfer phenotypic traits representing their cells of origin to secondary cells. Eur J Cancer. 2013;49:1845-59.

107. Safaei R, Larson BJ, Cheng TC, Gibson MA, Otani S, Naerdemann W, et al. Abnormal lysosomal trafficking and enhanced exosomal export of cisplatin in drug-resistant human ovarian carcinoma cells. Mol Cancer Ther. 2005;4:1595-604

108. Chen WX, Liu XM, Lv MM, Chen L, Zhao JH, Zhong SL, et al. Exosomes from drug-resistant breast cancer cells transmit chemoresistance by a horizontal transfer of microRNAs. PLoSOne. 2014;9:e95240.

109. Corcoran C, Rani S, O'Driscoll L. miR-34a is an intracellular and exosomal predictive biomarker for response to docetaxel with clinical relevance to prostate cancer progression. Prostate. 2014;74:1320-34. 
110. Munoz JL, Bliss SA, Greco SJ, Ramkissoon SH, Ligon KL, Rameshwar P. Delivery of Functional Anti-miR-9 by Mesenchymal Stem Cell-derived Exosomes to Glioblastoma Multiforme Cells Conferred Chemosensitivity. Mol Ther Nucleic Acids. 2013;2:e126.

111. Nana-Sinkam SP, Croce CM. MicroRNAs as therapeutic targets in cancer. Transl Res. 2011;157:216-25.

112. Krell J, Frampton AE, Stebbing J. MicroRNAs in the cancer clinic. Front Biosci. 2013;5:204-13.

113. Ling $H$, Fabbri M, Calin GA. MicroRNAs and other non-coding RNAs as targets for anticancer drug development. Nat Rev Drug Discov. 2013; 12:847-65

114. Lee HK, Finniss S, Cazacu S, Bucris E, Ziv-Av A, Xiang C, et al. Mesenchymal stem cells deliver synthetic microRNA mimics to glioma cells and glioma stem cells and inhibit their cell migration and self-renewal. Oncotarget. 2013:4:346-61.

115. Prokopi M, Kousparou CA, Epenetos AA. The Secret Role of microRNAs in Cancer Stem Cell Development and Potential Therapy: A Notch-Pathway Approach. Front Oncol. 2014;4:389.

116. Li XJ, Ren ZJ, Tang JH. MicroRNA-34a: a potential therapeutic target in human cancer. Cell Death Dis. 2014;5:e1327.

117. Ji Q, Hao X, Zhang M, Tang W, Yang M, Li L, et al. MicroRNA miR-34 inhibits human pancreatic cancer tumor-initiating cells. PLoSOne. 2009;4:e6816.

118. Yu G, Yao W, Xiao W, Li H, Xu H, Lang B. MicroRNA-34a functions as an antimetastatic microRNA and suppresses angiogenesis in bladder cancer by directly targeting CD44. J Exp Clin Cancer Res. 2014;33:779.

119. Johnson SM, Grosshans $H$, Shingara J, Byrom M, Jarvis R, Cheng A, et al. RAS is regulated by the let-7 microRNA family. Cell. 2005;120:635-47.

120. Liu C, Kelnar K, Liu B, Chen X, Calhoun-Davis T, Li H, et al. The microRNA miR-34a inhibits prostate cancer stem cells and metastasis by directly repressing CD44. Nat Med. 2011;17:211-5

121. Sampson $V B$, Rong NH, Han J, Yang $Q$, Aris V, Soteropoulos $P$, et al. MicroRNA let-7a down-regulates MYC and reverts MYC-induced growth in Burkitt lymphoma cells. Cancer Res. 2007;67:9762-70.

122. Sun X, Jiao X, Pestell TG, Fan C, Qin S, Mirabelli E, et al. MicroRNAs and cancer stem cells: the sword and the shield. Oncogene. 2014;33:4967-77.

123. Thornton JE, Gregory RI. How does Lin28 let-7 control development and disease? Trends Cell Biol. 2012;22:474-82.

124. Tsang WP, Kwok TT. Let-7a microRNA suppresses therapeutics-induced cancer cell death by targeting caspase-3. Apoptosis. 2008;13:1215-22.

125. Kobayashi M, Salomon C, Tapia J, Illanes SE, Mitchell MD, Rice GE. Ovarian cancer cell invasiveness is associated with discordant exosomal sequestration of Let-7 miRNA and miR-200. J Transl Med. 2014:12:4.

126. Wang W, Li J, Zhu W, Gao C, Jiang R, Li W, et al. MicroRNA-21 and the clinical outcomes of various carcinomas: a systematic review and meta-analysis. BMC Cancer. 2014;14:819.

127. Zhu W, Xu B. MicroRNA-21 identified as predictor of cancer outcome: a meta-analysis. PLoSOne. 2014;9:e103373.

128. Song B, Wang C, Liu J, Wang X, Lv L, Wei L, et al. MicroRNA-21 regulates breast cancer invasion partly by targeting tissue inhibitor of metalloproteinase 3 expression. J Exp Clin Cancer Res. 2010;29:29.

129. Mogilyansky E, Rigoutsos I. The miR-17/92 cluster: a comprehensive update on its genomics, genetics, functions and increasingly important and numerous roles in health and disease. Cell Death Differ. 2013;20:1603-14.

130. Bai Y, Sun Y, Peng J, Liao H, Gao H, Guo Y, et al. Overexpression of secretagogin inhibits cell apoptosis and induces chemoresistance in small cell lung cancer under the regulation of miR-494. Oncotarget. 2014:5:7760-75.

131. Cheng HH, Mitchell PS, Kroh EM, Dowell AE, Chery L, Siddiqui J, et al. Circulating microRNA profiling identifies a subset of metastatic prostate cancer patients with evidence of cancer-associated hypoxia. PLoSOne. 2013;8:e69239

132. Muller V, Gade S, Steinbach B, Loibl S, von Minckwitz G, Untch M, et al Changes in serum levels of miR-21, miR-210, and miR-373 in HER2-positive breast cancer patients undergoing neoadjuvant therapy: a translational research project within the Geparquinto trial. Breast Cancer Res Treat. 2014;147:61-8.

133. Qin Q, Furong W, Baosheng L. Multiple functions of hypoxia-regulated miR-210 in cancer. J Exp Clin Cancer Res. 2014;33:50.

134. Ma L, Young J, Prabhala H, Pan E, Mestdagh P, Muth D, et al. miR-9, a MYC/ MYCN-activated microRNA, regulates E-cadherin and cancer metastasis. Nat Cell Biol. 2010;12:247-56
135. Guglielmi L, Cinnella C, Nardella M, Maresca G, Valentini A, Mercanti D, et al. MYCN gene expression is required for the onset of the differentiation programme in neuroblastoma cells. Cell Death Dis. 2014;5:e1081.

136. Felli N, Fontana L, Pelosi E, Botta R, Bonci D, Facchiano F, et al. MicroRNAs 221 and 222 inhibit normal erythropoiesis and erythroleukemic cell growth via kit receptor down-modulation. Proc Natl Acad Sci U S A. 2005;102:18081-6.

137. Gillies JK, Lorimer IA. Regulation of p27Kip1 by miRNA 221/222 in glioblastoma. Cell Cycle. 2007;6:2005-9.

138. Kawaguchi T, Komatsu S, Ichikawa D, Morimura R, Tsujiura M, Konishi H, et al. Clinical impact of circulating miR-221 in plasma of patients with pancreatic cancer. Br J Cancer. 2013;108:361-9.

139. Park JK, Lee EJ, Esau C, Schmittgen TD. Antisense inhibition of microRNA-21 or -221 arrests cell cycle, induces apoptosis, and sensitizes the effects of gemcitabine in pancreatic adenocarcinoma. Pancreas. 2009:38:e190-9.

140. Teixeira AL, Ferreira M, Silva J, Gomes M, Dias F, Santos Jl, et al. Higher circulating expression levels of miR-221 associated with poor overall survival in renal cell carcinoma patients. Tumour Biol. 2014;35:4057-66.

141. Vaksman O, Stavnes HT, Kaern J, Trope CG, Davidson B, Reich R. miRNA profiling along tumour progression in ovarian carcinoma. JCell MolMed. 2011;15:1593-602.

142. Yang Y, Gu X, Zhou M, Xiang J, Chen Z. Serum microRNAs: A new diagnostic method for colorectal cancer. Biomed Rep. 2013;1:495-8.

143. Zhao JJ, Lin J, Yang H, Kong W, He L, Ma X, et al. MicroRNA-221/222 negatively regulates estrogen receptor alpha and is associated with tamoxifen resistance in breast cancer. J Biol Chem. 2008;283:31079-86.

144. Althoff K, Lindner S, Odersky A, Mestdagh P, Beckers A, Karczewski S, et al.: miR-542-3p exerts tumor suppressive functions in neuroblastoma by downregulating Survivin. Int J Cancer. 2014

145. Wang Y, Huang JW, Castella M, Huntsman DG, Taniguchi T. p53 is positively regulated by miR-542-3p. Cancer Res. 2014;74:3218-27.

146. Jiang JX, Gao S, Pan YZ, Yu C, Sun CY. Overexpression of microRNA-125b sensitizes human hepatocellular carcinoma cells to 5-fluorouracil through inhibition of glycolysis by targeting hexokinase II. Mol Med Rep. 2014;10:995-1002.

147. Liang L, Wong CM, Ying Q, Fan DN, Huang S, Ding J, et al. MicroRNA-125b suppressesed human liver cancer cell proliferation and metastasis by directly targeting oncogene LIN28B2. Hepatology. 2010;52:1731-40.

148. Zhou M, Liu Z, Zhao Y, Ding Y, Liu H, Xi Y, et al. MicroRNA-125b confers the resistance of breast cancer cells to paclitaxel through suppression of pro-apoptotic BCl-2 antagonist killer 1 (Bak1) expression. J Biol Chem. 2010;285:21496-507.

149. Li $Y$, Chao $Y$, Fang $Y$, Wang J, Wang $M$, Zhang $H$, et al. MTA1 promotes the invasion and migration of non-small cell lung cancer cells by downregulating miR-125b. J Exp Clin Cancer Res. 2013;32:33.

150. Honeywell DR, Cabrita MA, Zhao H, Dimitroulakos J, Addison CL. miR-105 inhibits prostate tumour growth by suppressing CDK6 levels. PLoSOne. 2013;8:e70515

151. Shen G, Rong X, Zhao J, Yang X, Li H, Jiang H, et al. MicroRNA-105 suppresses cell proliferation and inhibits PI3K/AKT signaling in human hepatocellular carcinoma. Carcinogenesis. 2014;35:2748-55.

152. Sirotkin AV, Laukova M, Ovcharenko D, Brenaut $P$, Mlyncek M. Identification of microRNAs controlling human ovarian cell proliferation and apoptosis. J Cell Physiol. 2010;223:49-56.

153. Yan W, Li R, Liu Y, Yang P, Wang Z, Zhang C, et al. MicroRNA expression patterns in the malignant progression of gliomas and a 5-microRNA signature for prognosis. Oncotarget. 2014;5:12908-15.

154. Schmitt MJ, Margue C, Behrmann I, Kreis S. MiRNA-29: a microRNA family with tumor-suppressing and immune-modulating properties. Curr Mol Med. 2013;13:572-85.

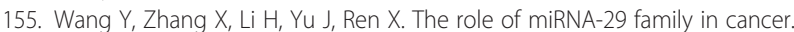
Eur J Cell Biol. 2013:92:123-8.

156. Wu Z, Huang X, Huang X, Zou Q, Guo Y. The inhibitory role of Mir-29 in growth of breast cancer cells. J Exp Clin Cancer Res. 2013;32:98. 